\title{
FRAGA, Olinta. A psique como eixo intermediário e criativo do fenômeno religioso cristão: uma análise a partir da teoria de Carl Gustav Jung focada na experiência de Paulo em 2 Cor 12. 2019. Dissertação (Mestrado em Ciências da Religião) - Pontifícia Universidade Católica de Minas Gerais, Belo Horizonte, 2019.*
}

\section{Resumo}

Este trabalho tem como objetivo uma análise da experiência de Paulo de Tarso em 2 Cor 12, tendo como referenciais teóricos a Psicologia Analítica e o conhecimento da psique conforme Jung hipostatizou. Jung nos revelou uma psique objetiva espontaneamente criativa e inteligente, que dialoga com a consciência em linguagem simbólica. É a fonte das fantasias que vão gerar os mitos, sonhos, visões, ideias, etc. $\mathrm{O}$ encontro entre Paulo e Cristo foi analisado como um fenômeno equivalente a um encontro direto de duas instâncias da psique: o ego, centro da consciência, e o Si-mesmo, centro da totalidade psíquica. Cristo é uma imagem de totalidade psíquica para Paulo e também um complexo. Dentro do alcance da fenomenologia empírica, trata-se de uma experiência direta com uma imagem arquetípica a qual define a numinosidade da experiência. Entende-se que Paulo de Tarso é um arquétipo de um ser humano que inicialmente foge de sua realização, sendo, na contemporaneidade, um arquétipo atualíssimo. A pesquisa foi bibliográfica e, conforme veremos no desenvolvimento do texto, em relação à questão identitária dos fenômenos, se metafísicos ou arquetípicos, não teremos

\footnotetext{
* Orientador: Prof. Dr. Fabiano Victor de Oliveira Campos. Defesa ocorrida em 19 de agosto de 2019. País de origem: Brasil. Email da autora: olinta.fraga@gmail.com
} 
resposta. A presente análise tem a pretensão de, sobretudo, apresentar novos ângulos dos fenômenos, sem intenção de levantar polêmicas sobre a ordem à qual pertençam.

Palavras-chave: Jung. Paulo de Tarso. Psique. Arquétipo. Fenômeno religioso.

\begin{abstract}
This research's purpose is to analyze the experience of Paulo de Tarso in 2 Cor 12, having the Analytical Psychology and the psyche's knowledge, as well as Jung has hypostasized, as theoretical references. Jung has revealed an objective psyche spontaneously creative and intelligent which dialogue with the conscience in symbolical language. It is a source of fantasies that will generate the myths, dreams, visions, ideas, etc. The encounter between Paulo and Christ was analyzed as a phenomenon equivalent to a direct encounter between the psyche's two instances: the ego, center of the consciousness, and the Self, center of the psychic totality. Christ is an image of psychic totality to Paulo and also a complex. Within the reach of the empirical phenomenology it is a direct experience with an archetypical image, which defines the experience's numinosity. It is understood that Paulo de Tarso is an archetype of a human being who initially escapes from his fulfilment, which is a very current archetype in the contemporaneity. This is a bibliographic research, where the identity issue of the phenomenon, whether metaphysical or archetypical, is still unanswered. However, the present objective analysis presents, above all, new angles of the phenomenon, without the intention of raising polemics about the order to which they belong.
\end{abstract}

Keywords: Jung. Paulo de Tarso. Psyche. Archetype. Religious Phenomenon. 